Sains Malaysiana 50(12)(2021): 3547-3556

http://doi.org/10.17576/jsm-2021-5012-07

\title{
Pengoptimuman Campuran Enzim Selulase Rekombinan untuk Penguraian Tandan Kosong Kelapa Sawit
}

(Optimization of Mixed Cellulase Enzymes for the Degradation of Oil Palm Empty Fruit Bunch)

\author{
Shazilah Kamaruddin*, Farah Diba Abu BaKar \& Abdul Munir Abdul Murad
}

\begin{abstract}
ABSTRAK
Penggunaan enzim selulase untuk penguraian biojisim pertanian lignoselulosa telah lama dikaji dan pelbagai usaha telah dilakukan untuk meningkatkan kecekapan proses hidrolisis. Keberkesanan penguraian biojisim pertanian kepada gula ringkas memerlukan satu campuran enzim yang mengandungi pelbagai jenis aktiviti selulolitik. Dalam kajian ini, satu campuran multi-enzim rekombinan yang terdiri daripada tiga komponen asas selulase iaitu endoglukanase (EglB) dan $\beta$-glukosidase (BglA) daripada Aspergillus niger serta selobiohidrolase (CbhII) daripada Trichoderma virens telah dibentuk khusus untuk hidrolisis tandan kosong kelapa sawit (TKKS). Penghasilan enzim selulase rekombinan telah dilakukan menggunakan hos pengekspresan Pichia pastoris. Pengoptimuman nisbah enzim untuk tindak balas ditentukan menggunakan Kaedah Gerak Balas Permukaan (RSM). Hasil menunjukkan hidrolisis TKKS pada suhu $50{ }^{\circ} \mathrm{C}$ dan pH 5.0 menggunakan enzim pada nisbah 641.4 unit CMCase: 10.14 unit Avicelase: 93.8 unit $\beta$-glukosidase, menghasilkan gula terturun dan glukosa tertinggi, masing-masing sebanyak 63 mg dan 40 mg per gram substrat TKKS. Hasil hidrolisis TKKS oleh campuran multi enzim yang telah dibentuk dalam kajian ini menunjukkan ketiga-tiga gabungan enzim rekombinan ini berpotensi untuk digunakan bagi penguraian TKKS.
\end{abstract}

Kata kunci: Biojisim pertanian; hidrolisis enzim; kaedah gerak balas permukaan; koktel enzim

\section{ABSTRACT}

The use of cellulase enzymes in the degradation of lignocellulose agriculture biomass has long been studied and various efforts have been made to improve the efficiency of the hydrolysis process. The efficiency of enzymatic degradation of agricultural biomass to simple sugars requires a mixture of enzymes containing various types of cellulolytic activity. In this study, a recombinant multi-enzyme mixture consisting of three basic components of cellulase namely endoglucanase (EglB) and $\beta$-glucosidase (BglA) from Aspergillus niger as well as cellobiohydrolase (CbhII) of Trichoderma virens was created specifically for hydrolysis of oil palm empty fruit bunch (OPEFB). The production of recombinant cellulases has been performed using Pichia pastoris expression host. The enzyme ratio optimisation was determined using Response Surface Methodology (RSM). The results showed that the hydrolysis of OPEFB at $50{ }^{\circ} \mathrm{C}$ and pH 5.0 using enzymes at 641.4 units CMCase: 10.14 Avicelase units: $93.8 \beta$-glucosidase units, produced the highest reducing sugar and glucose at $63 \mathrm{mg}$ and $40 \mathrm{mg}$ per gram of OPEFB substrate, respectively. The hydrolysis of OPEFB by a multi-enzyme mixture that has been formed in this study showed that these three combinations of recombinant enzymes have the potential to be used for the degradation of OPEFB.

Keywords: Agricultural biomass; enzymatic hydrolysis; enzyme cocktail; response surface methodology

\section{PENGENALAN}

Sebagai salah sebuah negara pengeluar minyak kelapa sawit utama dunia, industri ini merupakan industri berasaskan pertanian yang sangat penting di Malaysia (Bahadi et al. 2020). Namun begitu, industri ini telah menjana sekitar 40 juta tan sisa pepejal hasil pemprosesan buah kelapa sawit setahun. Sisa pepejal yang terhasil ini antaranya terdiri daripada gentian mesokarp kelapa sawit, rangka kernel kelapa sawit, pelepah, batang dan tandan kosong kelapa sawit (TKKS) (Chiew \& Shimada 2013; Loh 2017). Sebanyak 54\% daripada bahan buangan pepejal industri kelapa sawit adalah terdiri daripada TKKS iaitu sebanyak 20 hingga 24 juta tan (Chiew \& Shimada 2013; $\mathrm{Ng}$ et al. 2012). Biojisim yang bernilai ini kebiasaannya 
dilupuskan secara pembakaran mahupun digunakan sebagai bahan api di tapak pemprosesan kelapa sawit dan ini membawa kepada masalah pencemaran alam sekitar (Charpentier Alfaro \& Méndez Arias 2020; Derman et al. 2018; Noratiqah et al. 2013). Penggunaan enzim selulase untuk penguraian biojisim pertanian lignoselulosa telah lama dikaji dan pelbagai usaha telah dilakukan untuk meningkatkan keefisienan proses hidrolisis. Bagi tujuan tersebut, satu campuran enzim yang mengandungi pelbagai jenis aktiviti selulotik adalah penting bagi hidrolisis selulosa kepada glukosa (Adsul et al. 2020; Peciulyte et al. 2017). Sekurang-kurangnya tiga jenis selulase diperlukan untuk menukar selulosa kepada gula terlarut. Ini termasuk endoglukanase, eksoglukanase dan $\beta$-glukosidase (Rosales-Calderon \& Arantes 2019). Dalam satu campuran, kesemua enzim ini bertindak secara sinergi untuk menghidrolisis selulosa dengan masingmasing menyediakan kawasan hidrolisis baru yang boleh ditindakkan oleh enzim lain selain daripada membantu mengurangkan kesan perencatan oleh produk akhir (Lopes et al. 2018).

Namun begitu, keefisienan proses hidrolisis lignoselulosa oleh campuran enzim selulotik banyak bergantung kepada ciri biokimia enzim tersebut serta nisbah antara setiap enzim (Tang et al. 2018; Van Dyk \& Pletschke 2012). Selain itu, ciri kimia biojisim, jenis prarawatan dan pemuatan enzim yang digunakan dalam proses hidrolisis juga memberi kesan terhadap kecekapan penukaran selulosa kepada gula terturun (Wang et al. 2018). Justeru, untuk setiap biojisim yang berbeza dan melalui pra-rawatan berbeza, satu campuran enzim dengan profil yang khusus perlu dibentuk bagi mendapatkan proses hidrolisis yang optimum (Meyer et al. 2009). Ini dapat dilakukan menggunakan campuran enzim rekombinan yang telah dicirikan sifat biokimianya dan boleh disesuaikan dengan jenis substrat dan pra-rawatan. Pembentukan campuran enzim yang khusus untuk biojisim tertentu adalah sangat penting bagi meningkatkan keefisienan proses hidrolisis selain daripada mengurangkan pembaziran penggunaan enzim yang akan mempengaruhi kos keseluruhan proses.

Kaedah reka bentuk permukaan (RSM) merupakan satu kaedah yang diperkenalkan untuk melakukan pengoptimuman pelbagai faktor secara sistematik. Kaedah ini juga menganalisis interaksi antara pelbagai pemboleh ubah dalam kajian yang dilakukan (Fang et al. 2010; Zhou et al. 2009). Kaedah RSM ini telah banyak digunakan dalam pelbagai kajian untuk pengoptimuman enzim hidrolisis atau bioproses lain (Campos et al. 2020; Suwannarangsee et al. 2012).

Pelbagai kajian hidrolisis biojisim secara enzim telah dilakukan namun kajian hidrolisis khusus untuk substrat TKKS masih terhad (Charpentier Alfaro \& Méndez Arias 2020; Hamzah et al. 2011). Justeru, dalam kajian ini, satu campuran multi-enzim rekombinan separa tertulen yang terdiri daripada tiga komponen asas selulase iaitu endoglukanase, selobiohidrolase/ eksoglukanase dan $\beta$-glukosidase telah dibentuk khusus untuk hidrolisis TKKS. Nisbah setiap komponen enzim ini telah dioptimumkan menggunakan kaedah Central Composite Design (CCD) dengan menjadikan unit setiap komponen enzim ini sebagai pemboleh ubah untuk mendapatkan unit yang optimum. Pengetahuan yang diperoleh daripada kajian ini membolehkan pengenal pastian dan pengoptimuman gabungan enzim tertakrif khusus untuk hidrolisis TKKS dilakukan.

\section{BAHAN DAN KAEDAH}

\section{SUBSTRAT DAN PRA-RAWATAN}

Substrat lignoselulosa yang digunakan dalam kajian ini ialah tandan kosong kelapa sawit (TKKS) bersaiz $2 \mathrm{~mm}$ yang diperoleh daripada Universiti Putra Malaysia. Serabut ini telah dikisar dengan menggunakan mesin pengisar MF10 (IKA, USA) dan ditapis dengan penapis berukuran $0.5 \mathrm{~mm}$. Proses pra-rawatan dilakukan sebagaimana yang diterangkan oleh Chong et al. (2013) dengan sedikit pengubahsuaian. Dalam kajian ini, serabut TKKS direndam dalam campuran larutan yang mengandungi $70 \%$ gliserol (i/i) dan $1 \% \mathrm{H}_{2} \mathrm{SO}_{4}$ (i/i) pada nisbah 1:30 selama 3 jam pada suhu $120{ }^{\circ} \mathrm{C}$. TKKS kemudiannya dituras dengan menggunakan kain muslin dan dibasuh dengan air suling sehingga mencapai $\mathrm{pH}$ 7.0. Serabut TKKS ini kemudiannya dikeringkan pada suhu $65^{\circ} \mathrm{C}$ selama 2 hari sebelum digunakan.

\section{ENZIM SELULASE}

Enzim selulase rekombinan yang digunakan dalam kajian ini ialah endoglukanase (EglB), $\beta$-glukosidase (BglA) dan selobiohidrolase (CbhII) yang dihasilkan menggunakan sistem pengekspresan P. pastoris. Kultur klon EglB, CbhII dan BglA rekombinan pula diperoleh daripada stok kultur Makmal Mikologi Molekul, Jabatan Sains Biologi dan Bioteknologi, Fakulti Sains dan Teknologi, Universiti Kebangsaan Malaysia. Penghasilan kesemua enzim selulase rekombinan ini telah dilakukan berdasarkan kaedah yang telah diterangkan oleh Kamaruddin et al. (2018, 2015) dan Quay et al. (2017). Kesemua enzim rekombinan yang digunakan adalah enzim separa tulen yang diperoleh hasil penurasan ultra MWCO $10 \mathrm{kDa}$. Pengukuran selulase jumlah ditentukan melalui kaedah pengasaian kertas turas (FPU) berdasarkan kaedah yang diterangkan oleh Wood dan Bhat (1988). 
Nilai FPU hanya ditentukan untuk campuran selulase rekombinan EglB dan CbhII. Satu FPU ditakrif sebagai jumlah enzim yang diperlukan untuk menghasilkan 1 $\mu$ mol gula penurun (kesamaan glukosa) pada keadaan piawai. Seterusnya aktiviti $\beta$-glukosidase rekombinan kajian ini telah ditentukan berdasarkan kaedah yang telah diterangkan oleh Kamaruddin et al. (2015).

\section{HIDROLISIS TANDAN KOSONG KELAPA SAWIT}

Hidrolisis TKKS telah dijalankan pada keadaan piawai iaitu pada suhu $50{ }^{\circ} \mathrm{C}$ dalam penimbal natrium asetat $25 \mathrm{mM}$ pH 5 selama 18 jam. Isi padu tindak balas yang dilakukan adalah sebanyak $1 \mathrm{~mL}$ dan substrat TKKS yang digunakan adalah sebanyak 0.02 g. Kandungan gula terturun hasil hidrolisis TKKS pula ditentukan menggunakan kaedah pengasaian dinitrosalicylic acid (DNS) menggunakan glukosa sebagai piawai (Miller 1959). Penentuan kandungan glukosa pula menggunakan kit glucose-oxidase (GOD-PAP) berdasarkan kaedah oleh pengeluar (Roche Diagnostic, Switzerland).

\section{PENGOPTIMUMAN NISBAH CAMPURAN ENZIM}

MENGGUNAKAN KAEDAH CENTRAL COMPOSITE DESIGN (CCD)

Pengoptimuman nisbah campuran enzim rekombinan untuk hidrolisis TKKS telah dilakukan menggunakan kaedah CCD yang merupakan salah satu kaedah RSM dalam perisian Design Expert 6.0.4 (Stat-Ease, Inc, USA). Dalam kajian ini, pemboleh ubah yang dikaji adalah unit enzim selulase iaitu EglB, CbhII dan BglA. CCD tiga faktor yang mengandungi 20 set uji kaji dengan 6 ulangan di titik pertengahan telah digunakan untuk pengoptimuman nisbah unit EglB, CbhII dan BglA. Matlamat utama pengoptimuman ini dilakukan adalah untuk mendapatkan penghasilan gula terturun dan glukosa yang tertinggi daripada hidrolisis TKKS dan kerana itu kedua-dua faktor ini dijadikan respons dalam CCD. Seterusnya, sebanyak 6 set uji kaji untuk pengoptimuman telah dicadangkan daripada CCD dan kesemua set telah diuji bagi mendapatkan nisbah campuran enzim paling optimum. Untuk semua set uji kaji, sebanyak 2 ulangan biologi dan 3 ulangan teknikal telah dilakukan.

Campuran enzim selulase yang diperoleh hasil analisis CCD seterusnya dioptimumkan bagi meningkatkan keefisienan hidrolisis. Dua faktor telah dipilih iaitu masa hidrolisis dan juga jumlah unit enzim yang digunakan. Dalam kajian ini, pengoptimuman masa hidrolisis telah dilakukan pada suhu dan penimbal piawai dan dieram pada jumlah masa berbeza iaitu 1, 6, 12, 18, 24 dan 30 jam. Jumlah penghasilan gula terturun dan glukosa diukur bagi menentukan jangka masa optimum bagi hidrolisis TKKS.

Walaupun nisbah unit yang optimum antara ketigatiga enzim selulase telah ditentukan menggunakan kaedah reka bentuk uji kaji, pengoptimuman jumlah unit yang digunakan masih perlu dilakukan. Pengoptimuman jumlah unit selulase dilakukan dengan cara menggandakan setiap unit enzim yang diperoleh daripada hasil reka bentuk uji kaji. Faktor penggandaan yang digunakan adalah $\times 2, \times 4$ dan $\times 6$. Pengukuran gula terturun dan glukosa dilakukan bagi menentukan jumlah unit paling optimum bagi hidrolisis TKKS.

\section{HASIL}

\section{CIRI-CIRI PROTEIN REKOMBINAN SELULASE SEPARA TULEN}

Kesemua enzim rekombinan yang digunakan untuk hidrolisis TKKS ialah enzim separa tulen iaitu enzim ekstrak kasar yang dipekatkan secara penurasan ultra menggunakan turus pengempar berturas (Rajah 1).

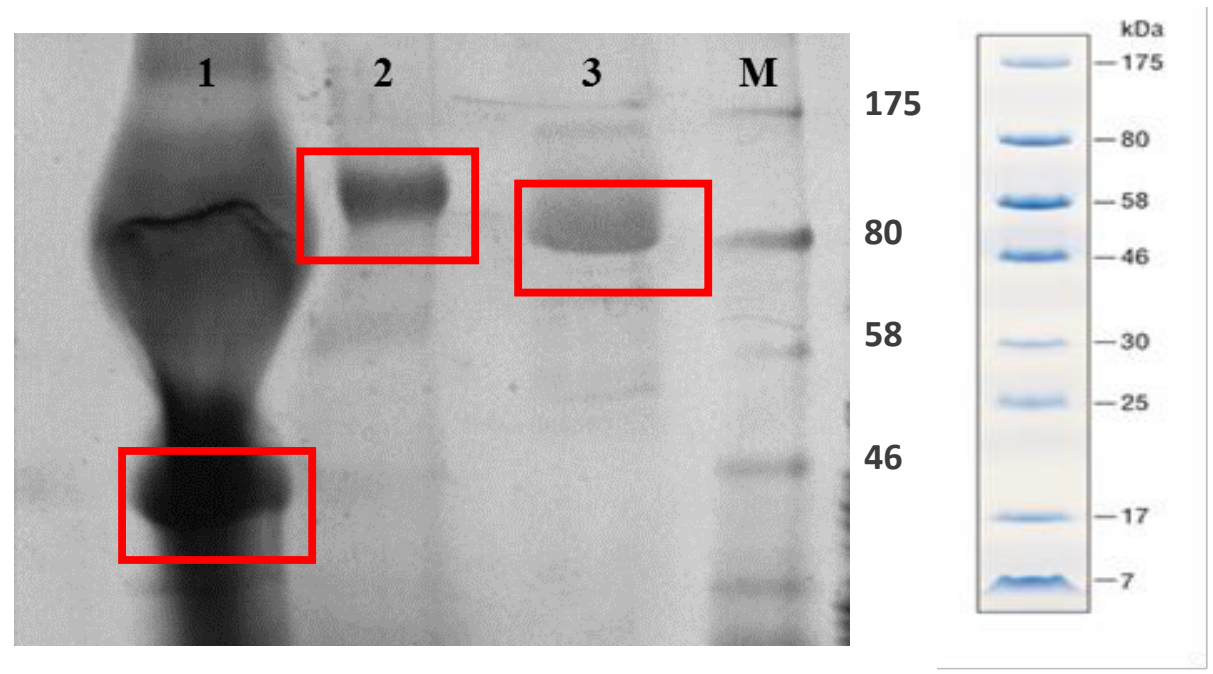

RAJAH 1. Profil SDS-PAGE enzim selulase rekombinan separa tulen yang berjaya dihasilkan oleh P. pastoris. Lajur 1: Enzim EglB rekombinan; Lajur 2: Enzim BglA rekombinan; Lajur 3: Enzim CbhII rekombinan; M: penanda berat molekul protein (NEB, USA) 
Jadual 1 menunjukkan perbandingan ciri biokimia antara ketiga-tiga selulase rekombinan. Ketiga-tiga enzim mempunyai aktiviti pada suhu optimum yang sama iaitu $50{ }^{\circ} \mathrm{C}$ tetapi mempunyai aktiviti optimum pada $\mathrm{pH}$ yang berbeza iaitu EglB dan BglA aktif pada $\mathrm{pH} 4$ manakala CbhII pula aktif pada $\mathrm{pH}$ 6. Justeru, satu titik $\mathrm{pH}$ perlu dipilih bagi membolehkan ketiga-tiga enzim ini bertindak pada tahap yang optimum apabila dicampurkan. Dalam hal ini pH 5 telah dipilih kerana pada pH ini, aktiviti ketigatiga jenis enzim adalah pada keadaan stabil dan aktif. Justeru, berdasarkan perbandingan yang telah dilakukan, suhu $50{ }^{\circ} \mathrm{C}$ dan $\mathrm{pH} 5.0$ telah dipilih sebagai keadaan optimum bagi ketiga-tiga enzim.

JADUAL 1. Perbandingan ciri-ciri biokimia enzim selulase rekombinan separa tulen

\begin{tabular}{lccc}
\hline Ciri-ciri enzim & EglB & CbhII & BglA \\
\hline pH optimum & 4.0 & 6.0 & 4.0 \\
Kestabilan pH & $5.0-8.0$ & $5.0-7.0$ & $3.0-6.0$ \\
Suhu optimum $\left({ }^{\circ} \mathrm{C}\right)$ & 50 & 50 & 50 \\
Kestabilan suhu $\left({ }^{\circ} \mathrm{C}\right)$ & $50-60$ & $30-45$ & $20-50$ \\
\hline
\end{tabular}

Seterusnya, penentuan kestabilan kesemua enzim ini pada suhu dan $\mathrm{pH}$ optimum yang dipilih telah diuji pada jangka masa 18 dan 24 jam. Ini bagi menentukan kestabilan ketiga-tiga enzim pada suhu dan $\mathrm{pH}$ yang telah ditetapkan pada jangka masa yang panjang disebabkan TKKS merupakan satu substrat yang kompleks (Derman et al. 2018). Justeru, hidrolisis TKKS perlu dilakukan pada kadar masa yang lebih lama berbanding substrat yang ringkas. Rajah 2 menunjukkan profil kestabilan kesemua enzim rekombinan selulase apabila dieramkan pada suhu $50{ }^{\circ} \mathrm{C}$, pH 5 selama 18 dan 24 jam. Kesemua enzim masih mempunyai sekurang-kurangnya $60 \%$ daripada aktiviti asalnya apabila dieramkan selama 18 jam pada $\mathrm{pH} 5$ dan $50{ }^{\circ} \mathrm{C}$. Pada jangka masa 24 jam pula, aktiviti CbhII telah menurun di bawah $60 \%$ berbanding enzim lain yang masih mempunyai lebih daripada $60 \%$ aktiviti. Justeru, jangka masa 18 jam telah dipilih untuk semua uji kaji pengoptimuman hidrolisis TKKS yang dijalankan.

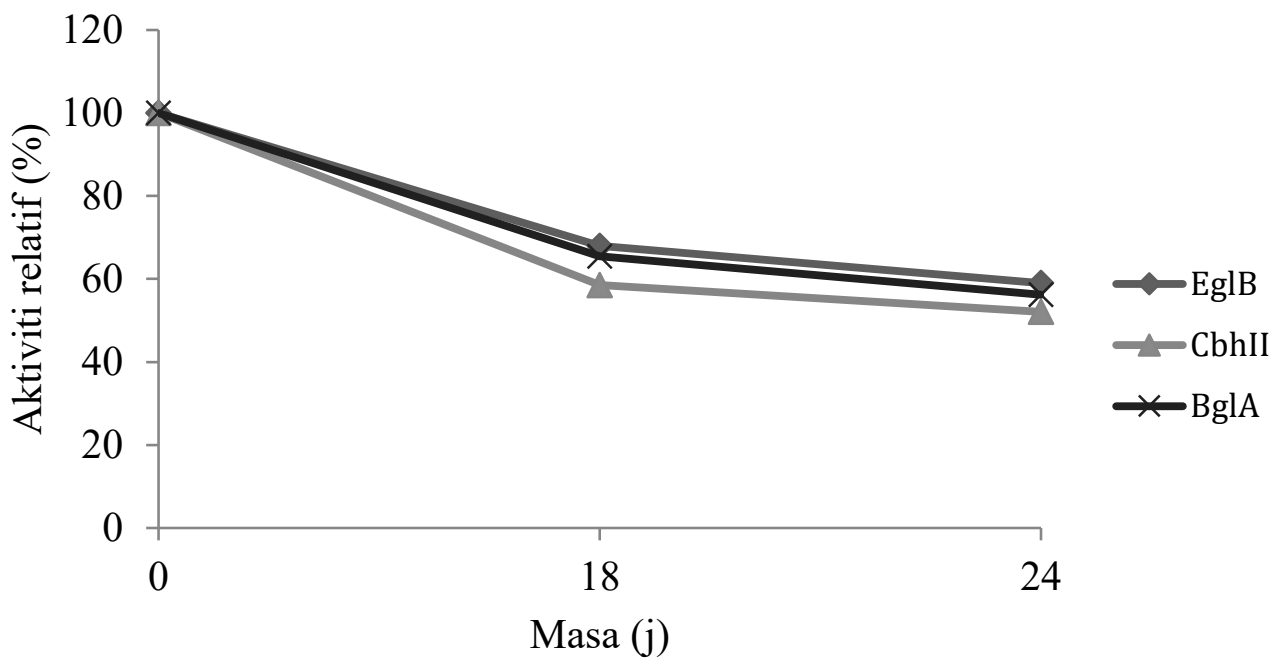

RAJAH 2. Profil kestabilan EglB, CbhII dan BglA pada $50{ }^{\circ} \mathrm{C} \mathrm{pH} 5$ 


\section{REKA BENTUK UJI KAJI CENTRAL COMPOSITE DESIGN (CCD)}

Pengoptimuman unit bagi setiap komponen enzim rekombinan ini adalah bagi melihat potensi penggunaan enzim rekombinan dalam hidrolisis substrat khusus iaitu TKKS. Ini seterusnya dapat membantu mengurangkan pembaziran enzim dan kos pengeluaran enzim untuk proses hidrolisis dan memaksimumkan hasil hidrolisis. Selain itu, penggunaan kaedah RSM dilihat lebih fleksibel dalam proses mereka bentuk uji kaji pengoptimuman yang mengandungi pelbagai pemboleh ubah. Di samping itu, kesan setiap pemboleh ubah yang diuji serta interaksi yang wujud di antara kesemua pemboleh ubah boleh ditentukan.

Hasil analisis kedua-dua respons (hasil gula terturun dan hasil glukosa) yang diperoleh daripada 20 set uji kaji CCD dengan 6 ulangan di titik pertengahan, Design Expert ${ }^{\circledR}$ 6.0.4 telah mencadangkan model penuh kuadratik bagi proses hidrolisis tersebut. Analisis varian (ANOVA) menunjukkan model yang diperoleh bagi keduadua respons adalah signifikan dari segi statistik kerana nilai $p$ (kebarangkalian $<$ F) model adalah lebih rendah daripada 0.0001. Nilai pekali regresi $\left(\mathrm{R}^{2}\right)$ bagi model respons gula terturun dan glukosa masing-masing adalah 0.9667 dan 0.9742 dan ini menunjukkan bahawa keduadua model ini adalah signifikan dan boleh digunakan. Kedua-dua model mempunyai nilai $\mathrm{R}^{2}$ pada julat yang hampir dengan nilai $\mathrm{R}^{2}$ terlaras. Di samping itu, nilai padanan kurang tepat (lack of fit) yang tidak signifikan menunjukkan bahawa model ini adalah tepat dan boleh digunakan untuk penentuan data uji kaji bagi hidrolisis TKKS (Jadual 2 dan 3).

JADUAL 2. Analisis ANOVA untuk respons gula terturun hasil daripada hidrolisis TKKS

\begin{tabular}{lccc}
\hline Sumber & Min Kuasa Dua & Nilai F & Kebarangkalian $>$ F \\
Model & 0.064 & 132.69 & 0.0001 \\
EglB & 0.017 & 34.54 & 0.0042 \\
CbhII & 0.084 & 174.00 & 0.0002 \\
BglA & 0.26 & 546.54 & $<0.0001$ \\
EglB-CbhII & $6.89 \times 10^{-3}$ & 14.35 & 0.0193 \\
EglB-BglA & $5.97 \times 10^{-3}$ & 12.43 & 0.0243 \\
CbhII-BglA & $7.38 \times 10^{-3}$ & 0.15 & 0.7152 \\
Padanan kurang tepat & $8.20 \times 10^{-6}$ & 0.013 & 0.9169 \\
\hline
\end{tabular}

$R^{2}=0.9967 ; R^{2}$ terlaras $=0.9892$

JADUAL 3. Analisis ANOVA untuk respons glukosa hasil daripada hidrolisis TKKS

\begin{tabular}{lccc}
\hline Sumber & Min Kuasa Dua & Nilai F & $\begin{array}{c}\text { Kebarangkalian }>\text { F } \\
(p)\end{array}$ \\
\hline Model & 0.035 & 16.79 & 0.0077 \\
EglB & $3.21 \times 10^{-4}$ & 0.16 & 0.7129 \\
CbhII & $4.57 \times 10^{-3}$ & 2.22 & 0.2107 \\
BglA & 0.3 & 143.62 & 0.0003 \\
EglB-CbhII & $1.01 \times 10^{-3}$ & 0.49 & 0.5231 \\
EglB-BglA & $1.32 \times 10^{-4}$ & 0.064 & 0.8126 \\
CbhII-BglA & $2.33 \times 10^{-3}$ & 1.13 & 0.3474 \\
Padanan kurang tepat & $1.04 \times 10^{-5}$ & $3.77 \times 10^{-3}$ & 0.9549 \\
\hline
\end{tabular}

$R^{2}=0.9742 ; R^{2}$ terlaras $=0.9162$ 
Hubung kait antara respons dan pemboleh ubah dapat dilihat pada permukaan respons yang telah dibina berdasarkan model kuadratik yang diperoleh (Rajah 3). Model ini juga menunjukkan wujudnya interaksi antara EglB-CbhII dan EglB-BglA terhadap penghasilan gula terturun. Namun begitu, tiada interaksi yang signifikan bagi CbhII-BglA yang memberi kesan terhadap dalam penghasilan gula terturun. Kajian oleh Kleman-Leyer et al. (1996) mendapati bahawa terdapat interaksi yang signifikan antara Egll dan CbhII T. reesei dalam penghasilan gula terturun daripada selulosa kapas. Interaksi endo-ekso ini adalah terbit daripada tindakan eksoglukanase terhadap rantaian polisakarida yang baru hasil tindakan oleh endoglukanase. Kajian oleh Wood dan McCrae (1979) telah mencadangkan model klasik hubungan sinergi antara endo-ekso dalam penguraian selulosa enzim. Endoglukanase bertindak pada kawasan amorfus selulosa dan membentuk tapak yang baru untuk tindakan oleh eksoglukanase. Tindakan enzim oleh eksoglukanase pula akan menghasilkan lebih banyak tapak dan ruang untuk dicapai oleh endoglukanase terutamanya pada kawasan berkristal. Ini seterusnya menyumbang kepada peningkatan gula terturun. Selain itu, didapati hanya BglA sahaja yang merupakan faktor signifikan yang mempengaruhi penghasilan glukosa dalam hidrolisis TKKS. Ini menunjukkan dalam hidrolisis TKKS, EglB dan CbhII lebih banyak menghasilkan rantaian polisakarida berbanding glukosa. Dalam hal ini, penghasilan glukosa adalah lebih bergantung kepada BglA yang bertindak ke atas selobiosa.

Bagi membentuk satu campuran enzim untuk diaplikasikan dalam proses hidrolisis sesuatu biojisim lignoselulosa, pemahaman tentang ciri dan nisbah setiap komponen enzim yang hendak digunakan adalah penting. Rajah 3(a) menunjukkan plot 3D bagi pengaruh enzim EglB dan BglA terhadap penghasilan gula terturun. Berdasarkan rajah ini, penghasilan gula terturun paling tinggi dapat dicapai apabila unit EglB dan BglA

a)

b)
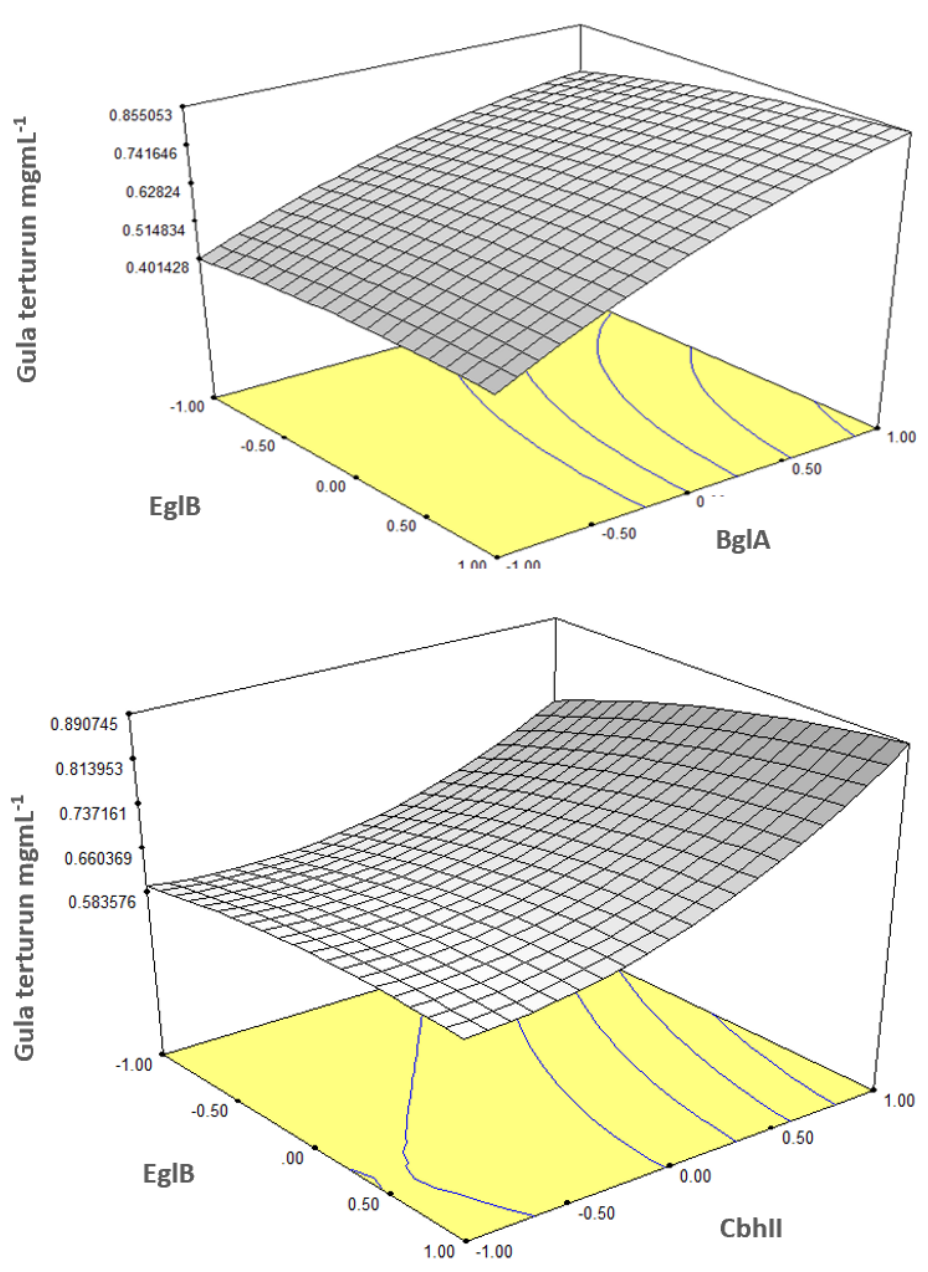

RAJAH 3. Plot 3D permukaan respons gula terturun bagi pemboleh ubah yang mempunyai interaksi yang signifikan (a) EglB-BglA (b) EglB-CbhII 
adalah maksimum. Penghasilan gula terturun adalah paling rendah apabila unit enzim BglA berada pada tahap minimum walaupun unit EglB ditingkatkan. Profil analisis plot 3D antara unit EglB dan CbhII pula menunjukkan penghasilan gula tertinggi dapat dicapai dengan penggunaan unit EglB yang maksimum bersama 33/4 unit CbhII (Rajah 3(b)). Peningkatan unit CbhII melebihi 33/4 unit tidak akan meningkatkan penghasilan gula terturun. Dalam kajian ini, dilihat campuran enzim optimum dapat dicapai dengan menggunakan unit aktiviti endoglukanase yang paling tinggi berbanding unit eksoglukanase. Walau bagaimanapun, terdapat variasi tentang nisbah selulase yang digunakan dalam kajian lain. Sesetengah kajian menunjukkan nisbah endoglukanase yang lebih tinggi terhadap eksoglukanase adalah lebih baik manakala banyak juga kajian yang menggunakan nisbah yang sebaliknya dalam proses hidrolisis selulase (Bunterngsook et al. 2018; Tang et al. 2018; Van Dyk \& Pletschke 2012). Variasi ini berkemungkinan disebabkan perbezaan jenis substrat dan proses pra-rawatan yang dijalankan terhadap substrat tersebut. Justeru, penggunaan satu campuran enzim dengan profil yang tertentu khusus untuk setiap biojisim yang berbeza serta pra-rawatan berbeza adalah penting bagi mendapatkan satu proses hidrolisis yang optimum (Meyer et al. 2009). Selain itu, pengoptimuman menggunakan unit enzim relatif kepada jumlah substrat yang digunakan adalah penting terutamanya dalam menentukan kesan penambahan enzim terhadap kos keseluruhan hidrolisis sesuatu substrat (Van Dyk \& Pletschke 2012).

\section{PENGESAHSAHIHAN MODEL}

Untuk mendapatkan hasil hidrolisis TKKS yang maksimum, parameter sasaran respons iaitu gula terturun dan glukosa telah ditetapkan kepada maksimum. Beberapa penyelesaian yang telah dijana diuji (Jadual 4). Dalam hal ini, semakin tinggi nilai kebolehcapaian semakin tinggi kesahihan model tersebut. Jadual 4 menunjukkan uji kaji 2 memberi hasil hidrolisis yang terbaik. Nilai hasil gula terturun dan glukosa jangkaan adalah masing-masing 55.9 dan $29.0 \mathrm{mg} / \mathrm{g}$ manakala nilai hasil uji kaji masingmasing adalah 48.0 dan $22.6 \mathrm{mg} / \mathrm{g}$. Berdasarkan data tersebut, nilai respons daripada uji kaji adalah berada di sekitar nilai jangkaan. Justeru, jelas terdapat korelasi yang baik antara hasil uji kaji dengan hasil jangkaan seterusnya membuktikan kesahihan model yang telah dijana ini.

JADUAL 4. Pengoptimuman nisbah unit enzim selulase berdasarkan uji kaji pengoptimuman yang dicadangkan oleh CCD

\begin{tabular}{|c|c|c|c|c|c|c|c|c|c|}
\hline Uji kaji & $\operatorname{EglB}(U)$ & CbhII (U) & $\operatorname{BglA}(U)$ & $\begin{array}{c}\text { Jumlah Unit } \\
\text { (U) }\end{array}$ & Kebolehcapaian & $\begin{array}{c}\text { Gula } \\
\text { terturun } \\
\text { jangkaan } \\
(\mathrm{mg} / \mathrm{g})^{\mathrm{a}}\end{array}$ & $\begin{array}{c}\text { Gula } \\
\text { terturun uji } \\
\text { kaji }(\mathrm{mg} / \mathrm{g})^{\mathrm{a}}\end{array}$ & $\begin{array}{c}\text { Glukosa } \\
\text { jangkaan } \\
(\mathrm{mg} / \mathrm{g})^{\mathrm{a}}\end{array}$ & $\begin{array}{l}\text { Glukosa uji } \\
\text { kaji }(\mathrm{mg} / \mathrm{g})^{\mathrm{a}}\end{array}$ \\
\hline 1 & 3.155 & 0.046 & 0.315 & 3.515 & 0.802 & 47.7 & 33.22 & 21.9 & 21.48 \\
\hline 2 & 3.207 & 0.051 & 0.469 & 3.727 & 1 & 55.9 & 48.02 & 29.0 & 22.59 \\
\hline 3 & 3.448 & 0.046 & 0.315 & 3.808 & 0.818 & 49.2 & 33.42 & 23.4 & 19.49 \\
\hline 4 & 3.517 & 0.046 & 0.441 & 4.003 & 1 & 60.0 & 37.34 & 29.8 & 20.16 \\
\hline 5 & 3.301 & 0.040 & 0.161 & 3.502 & 1 & 52.6 & 25.66 & 25.4 & 16.34 \\
\hline 6 & 3.300 & 0.040 & 0.470 & 3.810 & 0.981 & 57.9 & 32.82 & 23.2 & 22.50 \\
\hline
\end{tabular}

a nilai mewakili jumlah mg gula terturun atau glukosa yang dihasilkan bagi setiap gram susbtrat TKKS yang dihidrolisis

\section{KESAN JUMLAH PEMUATAN ENZIM DAN MASA HIDROLISIS}

Selepas campuran selulase rekombinan dengan nisbah optimum diperoleh daripada CCD, campuran ini kemudiannya dioptimumkan lagi dari segi pemuatan enzim dan masa hidrolisis bagi mendapatkan hasil yang maksimum. Rajah 4 menunjukkan jumlah unit sebanyak empat kali ganda lebih tinggi daripada unit asal yang diperoleh daripada CCD adalah optimum dari segi penghasilan kedua-dua produk iaitu gula terturun 
dan glukosa. Penambahan unit lebih daripada empat kali ganda menunjukkan sedikit peningkatan dari segi penghasilan gula terturun tetapi tiada perubahan dapat dilihat dari segi penghasilan glukosa. Rajah 5 pula menunjukkan masa hidrolisis TKKS yang paling optimum bagi campuran enzim ini adalah selama 18 jam. Penggunaan masa hidrolisis yang lebih panjang tidak menunjukkan peningkatan dari segi penghasilan gula terturun dan glukosa. Justeru, jumlah unit paling optimum untuk hidrolisis TKKS adalah pada nisbah unit enzim 641.4 unit CMCase: 10.14 unit Avicelase: 93.8 unit $\beta$-glukosidase per gram substrat TKKS.

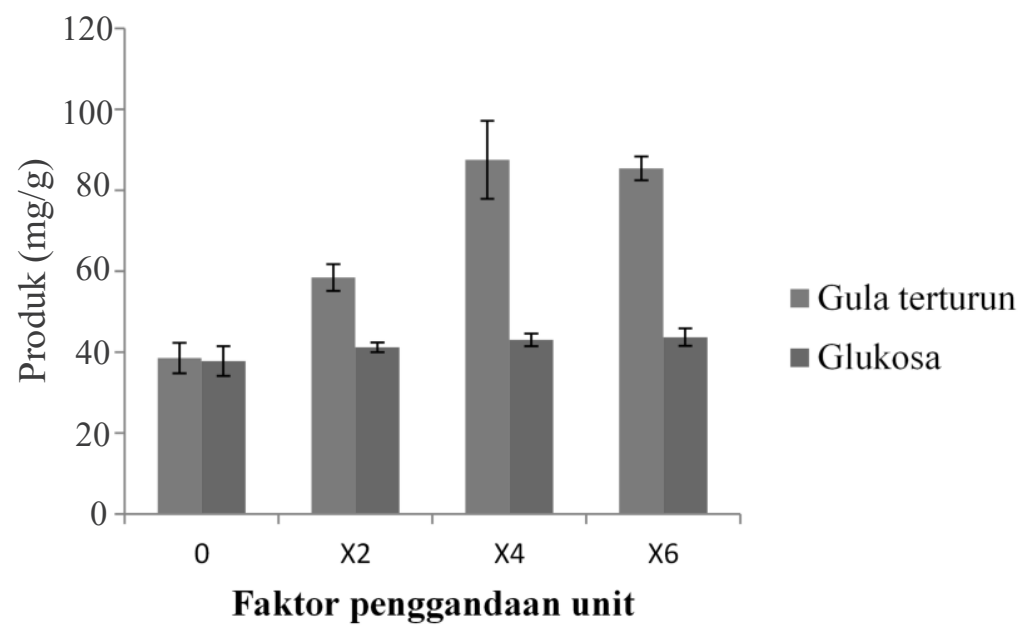

RAJAH 4. Pengoptimuman pemuatan enzim/jumlah enzim untuk hidrolisis TKKS

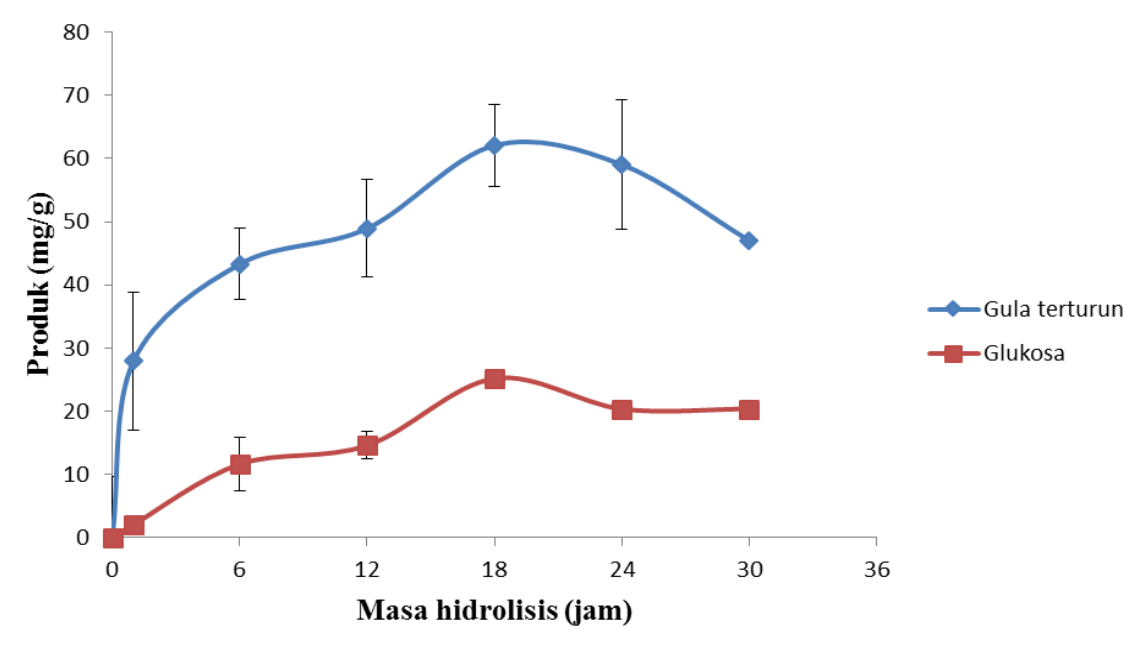

RAJAH 5. Pengoptimuman masa untuk hidrolisis TKKS

Seterusnya, nilai aktiviti selulase jumlah telah ditentukan berdasarkan kaedah piawai yang digunakan di seluruh dunia iaitu pengasaian kertas turas yang dikeluarkan oleh Kesatuan Antarabangsa Kimia Tulen dan Gunaan (IUPAC). Pengasaian kertas turas digunakan secara meluas di seluruh dunia dalam menentukan aktiviti campuran selulase dan pengasaian yang dilakukan boleh memberikan keputusan yang boleh diulang (Coward-Kelly et al. 2003; Decker et al. 2003). Nilai FPU bagi campuran enzim rekombinan EglB dan CbhII mengikut nisbah 641.4 unit CMCase: 10.14 unit Avicelase: 93.8 adalah 1.1 FPU unit per gram TKKS. 
Hidrolisis TKKS menggunakan 1.1 FPU unit selulase rekombinan selama 18 jam telah menghasilkan sebanyak $63 \mathrm{mg} / \mathrm{g}$ gula terturun dan $40 \mathrm{mg} / \mathrm{g}$ glukosa. Jumlah unit FPU yang digunakan dalam kajian ini lebih rendah berbanding unit FPU yang digunakan dalam kajian yang dilakukan oleh Hamzah et al. (2011). Dalam kajian tersebut, sebanyak 98.4 FPU/mL selulase sediaan komersial (Sigma Aldrich, USA) digunakan untuk hidrolisis TKKS terawat alkali dan menghasilkan sebanyak $33.8 \mathrm{mg} / \mathrm{g}$ glukosa.

\section{KESIMPULAN}

Pengoptimuman bagi membentuk campuran multienzim khusus untuk hidrolisis TKKS menggunakan tiga komponen selulase iaitu EglB, CbhII dan BglA terbitan $P$. pastoris telah dilakukan menggunakan kaedah RSM. Nisbah unit optimum bagi campuran ini ialah 641.4 unit CMCase: 10.14 unit Avicelase: 93.8 unit $\beta$-glukosidase atau 1.1 FPU per gram substrat TKKS dengan penghasilan gula terturun dan glukosa masingmasing sebanyak 63 dan $40 \mathrm{mg} / \mathrm{g}$. Konsep campuran enzim tertakrif yang digunakan dalam kajian ini membolehkan kawalan terhadap jumlah dan jenis enzim yang penting untuk hidrolisis sesuatu substrat dilakukan bagi mengurangkan kos keseluruhan proses penguraian di samping meningkatkan keefisienannya. Selain itu, kaedah ini membolehkan penambahbaikan campuran enzim mengikut kehendak proses seperti $\mathrm{pH}$ dan suhu yang tertentu dilakukan dengan mudah. Ini kerana setiap komponen enzim yang hendak digunakan dapat dicirikan dan dipilih secara terperinci mengikut jenis substrat dan pra-rawatan. Strategi ini dilihat dapat meningkatkan keefisienan proses hidrolisis bahan lignoselulosa yang khusus di samping penggunaan enzim yang lebih rational dan optimum untuk sesuatu biojisim.

\section{PENGHARGAAN}

Penyelidikan ini telah dibiayai oleh geran penyelidikan 07-05-16-MGI-GMB12 daripada Kementerian Sains, Teknologi dan Inovasi, Malaysia.

\section{RUJUKAN}

Adsul, M., Sandhu, S.K., Singhania, R.R., Gupta, R., Puri, S.K. \& Mathur, A. 2020. Designing a cellulolytic enzyme cocktail for the efficient and economical conversion of lignocellulosic biomass to biofuels. Enzyme and Microbial Technology 133(109442): 1-12.

Bahadi, M., Yusoff, M.F., Salimon, J. \& Derawi, D. 2020. Optimization of response surface methodology by D-optimal design for alkaline hydrolysis of crude palm kernel oil. Sains Malaysiana 49(1): 29-41.
Bunterngsook, B., Laothanachareon, T., Chotirotsukon, C., Inoue, H., Fujii, T., Hoshino, T., Roongsawang, N., Kuboon, S., Kraithong, W., Techanan, W., Kraikul, N. \& Champreda, V. 2018. Development of tailor-made synergistic cellulolytic enzyme system for saccharification of steam exploded sugarcane bagasse. Journal of Bioscience and Bioengineering 125(4): 390-396.

Campos, L.M.A., Moura, H.O.M.A., Cruz, A.J.G., Assumpção, S.M.N., de Carvalho, L.S. \& Pontes, L.A.M. 2020. Response surface methodology (RSM) for assessing the effects of pretreatment, feedstock, and enzyme complex association on cellulose hydrolysis. Biomass Conversion and Biorefinery https://doi.org/10.1007/s13399-020-00756-4.

Charpentier Alfaro, C. \& Méndez Arias, J. 2020. Enzymatic conversion of treated oil palm empty fruit bunches fiber into fermentable sugars: Optimization of solid and protein loadings and surfactant effects. Biomass Conversion and Biorefinery https://doi.org/10.1007/s13399-020-00724-y.

Chiew, Y.L. \& Shimada, S. 2013. Current state and environmental impact assessment for utilizing oil palm empty fruit bunches for fuel, fiber and fertilizer - A case study of Malaysia. Biomass and Bioenergy 51: 109-124.

Chong, P.S., Jahim, J.M., Harun, S., Lim, S.S., Mutalib, S.A., Hassan, O. \& Nor, M.T.M. 2013. Enhancement of batch biohydrogen production from prehydrolysate of acid treated oil palm empty fruit bunch. International Journal of Hydrogen Energy 38(22): 9592-9599.

Coward-Kelly, G., Aiello-Mazzari, C., Kim, S., Granda, C. \& Holtzapple, M. 2003. Suggested improvements to the standard filter paper assay used to measure cellulase activity. Biotechnology and Bioengineering 82(6): 745-749.

Decker, S.R., Adney, W.S., Jennings, E., Vinzant, T.B. \& Himmel, M.E. 2003. Automated filter paper assay for determination of cellulase activity. Applied Biochemistry and Biotechnology 107(1-3): 689-703.

Derman, E., Abdulla, R., Marbawi, H. \& Sabullah, M.K. 2018. Oil palm empty fruit bunches as a promising feedstock for bioethanol production in Malaysia. Renewable Energy 129: 285-298.

Fang, H., Zhao, C. \& Song, X.Y. 2010. Optimization of enzymatic hydrolysis of steam-exploded corn stover by two approaches: Response surface methodology or using cellulase from mixed cultures of Trichoderma reesei RUT-C30 and Aspergillus niger NL02. Bioresource Technology 101(11): 4111-4119.

Hamzah, F., Idris, A. \& Shuan, T.K. 2011. Preliminary study on enzymatic hydrolysis of treated oil palm (Elaeis) empty fruit bunches fibre (EFB) by using combination of cellulase and $\beta$ 1-4 glucosidase. Biomass and Bioenergy 35(3): 1055-1059.

Kamaruddin, S., Abu Bakar, F.D., Illias, R.M., Said, M., Hassan, O. \& Murad, A.M.A. 2015. Overexpression, purification and characterization of Aspergillus niger beta-glucosidase in Pichia pastoris. Malaysian Applied Biology 44: 7-11.

Kamaruddin, S., Mahadi, N.M., Md Illias, R., Hassan, O., Sulaiman, S., Broughton, W., Bharudin, I., Abu Bakar, F.D. 
\& Abdul Murad, A.M. 2018. Effect of Pichia pastoris host strain on the properties of recombinant Aspergillus niger endoglucanase, EglB. Malaysian Journal of Microbiology 14(6): 554-562.

Kleman-Leyer, K.M., Siika-Aho, M., Teeri, T.T. \& Kent Kirk, T. 1996. The cellulases endoglucanase I and cellobiohydrolase II of Trichoderma reesei act synergistically to solubilize native cotton cellulose but not to decrease its molecular size. Applied and Environmental Microbiology 62(8): 2883-2887.

Loh, S.K. 2017. The potential of the Malaysian oil palm biomass as a renewable energy source. Energy Conversion and Management 141: 285-298.

Lopes, A.M., Ferreira Filho, E.X. \& Moreira, L.R.S. 2018. An update on enzymatic cocktails for lignocellulose breakdown. Journal of Applied Microbiology 125(3): 632645.

Meyer, A.S., Rosgaard, L. \& Sørensen, H.R. 2009. The minimal enzyme cocktail concept for biomass processing. Journal of Cereal Science 50(3): 337-344.

Miller, G.L. 1959. Use of dinitrosalicylic acid reagent for determination of reducing sugar. Analytical Chemistry 31(3): 426-428

Ng, W.P.Q., Lam, H.L., Ng, F.Y., Kamal, M. \& Lim, J.H.E. 2012. Waste-to-wealth: Green potential from palm biomass in Malaysia. Journal of Cleaner Production 34: 57-65.

Noratiqah, K., Madihah, M.S., Aisyah, B.S., Eva, M.S., Suraini, A.A. \& Kamarulzaman, K. 2013. Statistical optimization of enzymatic degradation process for oil palm empty fruit bunch (OPEFB) in rotary drum bioreactor using crude cellulase produced from Aspergillus niger EFB1. Biochemical Engineering Journal 75: 8-20.

Peciulyte, A., Pisano, M., de Vries, R.P. \& Olsson, L. 2017. Hydrolytic potential of five fungal supernatants to enhance a commercial enzyme cocktail. Biotechnology Letters 39(9): 1403-1411.

Quay, D.H.X., Yee, Y.H., Illias, R.M., Mahadi, N.M., Bakar, F.D.A. \& Murad, A.M.A. 2017. Characterisation of recombinant Trichoderma reesei cellobiohydrolase and the potential of cellulase mixture in hydrolyzing oil palm empty fruit bunches. Malaysian Applied Biology 46: 11-19.

Rosales-Calderon, O. \& Arantes, V. 2019. A review on commercial-scale high-value products that can be produced alongside cellulosic ethanol. Biotechnology for Biofuels 12(240): 1-58.
Suwannarangsee, S., Bunterngsook, B., Arnthong, J., Paemanee, A., Thamchaipenet, A., Eurwilaichitr, L., Laosiripojana, N. \& Champreda, V. 2012. Optimisation of synergistic biomass-degrading enzyme systems for efficient rice straw hydrolysis using an experimental mixture design. Bioresource Technology 119: 252-261.

Tang, P.L., Abdul, P.M., Engliman, N.S. \& Hassan, O. 2018. Effects of pretreatment and enzyme cocktail composition on the sugars production from oil palm empty fruit bunch fiber (OPEFBF). Cellulose 25(8): 4677-4694.

Van Dyk, J.S. \& Pletschke, B.I. 2012. A review of lignocellulose bioconversion using enzymatic hydrolysis and synergistic cooperation between enzymes - Factors affecting enzymes, conversion and synergy. Biotechnology Advances 30(6): $1458-1480$

Wang, Z., Winestrand, S., Gillgren, T. \& Jönsson, L.J. 2018. Chemical and structural factors influencing enzymatic saccharification of wood from aspen, birch and spruce. Biomass and Bioenergy 109: 125-134.

Wood, T. \& McCrae, S.I. 1979. Synergism between enzymes involved in the solubilization of native cellulose. Advances in Chemistry Series 181: 181-209.

Wood, T.M. \& Bhat, K.M. 1988. Methods for measuring cellulase activities. Methods in Enzymology 160: 87-112.

Zhou, J., Wang, Y.H., Chu, J., Luo, L.Z., Zhuang, Y.P. \& Zhang, S.L. 2009. Optimization of cellulase mixture for efficient hydrolysis of steam-exploded corn stover by statistically designed experiments. Bioresource Technology 100(2): 819-825.

Department of Biological Sciences and Biotechnology Faculty of Science and Technology

Universiti Kebangsaan Malaysia 43600 UKM Bangi, Selangor Darul Ehsan Malaysia

*Corresponding author; email: shazilah@ukm.edu.my

Received: 28 September 2020

Accepted: 16 April 2021 